\title{
A Literature Review of Directors' Supervising Managers: Based on the Comparison of Equity Incentives and Monetary Salary Incentives
}

\author{
Xiangyu Li \\ School of Management, Jinan University, Guangzhou, China \\ Email: xiangyu_2211@126.com
}

How to cite this paper: Li, X.Y. (2019) A Literature Review of Directors' Supervising Managers: Based on the Comparison of Equity Incentives and Monetary Salary Incentives. Modern Economy, 10, 1190-1197. https://doi.org/10.4236/me.2019.104081

Received: March 11, 2019

Accepted: April 16, 2019

Published: April 19, 2019

Copyright $\odot 2019$ by author(s) and Scientific Research Publishing Inc. This work is licensed under the Creative Commons Attribution International License (CC BY 4.0).

http://creativecommons.org/licenses/by/4.0/

\section{cc (i) Open Access}

\begin{abstract}
This paper analyzes the relevant literature on directors' supervision of managers in terms of monetary compensation incentives and equity incentives. By comparing the advantages and disadvantages of monetary compensation incentives and equity incentives in the supervision of managers by directors, this paper believes that equity incentives can more clearly discover the supervisory supervision of directors. At the same time, this paper believes that in the case of equity incentives, joint incentives for directors and managers can promote the supervision of directors. The analysis conclusions of this paper have guiding significance in the actual corporate governance process.
\end{abstract}

\section{Keywords}

Directors, Managers, Supervision, Equity Incentives, Monetary Compensation Incentive

\section{Introduction}

The main research purpose of this paper is to analyze whether the supervision of directors can promote the effective implementation of equity incentive plan in the context of the implementation of equity incentives from the perspective of literature review. From the perspective of corporate governance, the role of directors is to supervise the management and decision-making of managers. However, from the perspective of principal-agent theory, the agency problem between managers and shareholders is obvious. Can the supervisory role of directors weaken such agency problems? From the current research literature and the practice of corporate governance, the use of equity incentives has increasingly become an arrangement to solve the above-mentioned agency problems. 
The supervision of directors will inevitably have a significant impact on equity incentives. At the same time, the supervision of directors is directly related to whether the equity incentive plan can reduce the above-mentioned agency problem, that is, the effectiveness of the equity incentive plan.

The main content of this paper is that the directors supervise the main documents of managers by separately reviewing monetary compensation incentives and equity incentives. Then, the above two aspects of the literature are summarized, comparing the advantages of equity incentives relative to monetary compensation incentives when analyzing directors' supervisory managers. Finally, based on the theory of optimal compensation contract and risk sharing hypothesis, this paper analyzes the advantages of jointly encouraging incentives for directors and managers in the implementation of equity incentive plans, and promoting the effectiveness of equity incentive plans and the supervisory role of directors; and analyzes the feasibility of jointly encouraging directors and managers when designing equity incentive plans. At the same time, the research suggestions of this paper are given.

\section{A Literature Review on Directors' Supervision of Managers: From the Perspective of Monetary Salary Incentives}

Since 1990, the relevant literature supervised by the board of directors has emerged in an endless stream. Brick et al., found that after the "Sarbanes-Oxley" bill was enacted in 2002, the company increased its supervisory function [1]. As an integral part of corporate governance, the board of directors mostly focuses on the size of the board of directors and the structure of the board of directors. For example, Linck proposes that the board structure of companies of different sizes is consistent with the cost benefits of board supervision and recommendations [2]. At the same time, it was found that higher growth opportunities, higher R\&D expenditures, and higher fluctuations in stock returns are often associated with smaller companies and companies with weaker board independence. Similarly, board monitoring activities such as the frequency of board meetings and structural changes in board committees are also of concern to researchers. Vafeas found that the frequency of board meetings and the more frequent board activities, the company's stock price will fall, resulting in lower corporate value [3]. The Brick study draws the same conclusion. According to further research by Faleye, the board of directors plays two main roles, namely supervision and consultation [4]. Monitoring roles include oversight management to reduce potential agency problems, while consulting roles include assisting managers in strategy development and execution, and advising seniors in making decisions in other areas. Most of the responsibilities of the board of directors are completed by the committee, which mainly includes the audit committee, the remuneration committee and the nomination committee. The Audit Committee oversees the financial reporting and internal control systems, while the Compensation Committee is responsible for managing and reviewing all executive compensation 
plans. The Nominating Committee is responsible for assessing the performance of candidates, individual directors, and assessing the company's governance structure. These functions form the primary oversight function of the board of directors. Brick \& Chidambaran studied the ways in which the supervisory function of the board of directors affects the company's performance [5]. Research shows that the board's supervisory motivation is corporate activities, such as acquisitions and financial statement restatement, which affects company performance. Cornelli et al. found that the board of directors can better understand the CEO's ability by collecting information; compared to hard data, "soft" information can better make the board understand the CEO [6]. Miletkov examines the impact of board independence on the company's ability to attract external investors and finds that investors prefer companies with stronger independent directors [7]. The author further finds that in countries where the legal system for protecting investors is imperfect, the independence of the board of directors is significantly positively correlated with the number of shares held by foreign shareholders. The author also found that the independence of the board of directors affects the company's performance, that is, companies with higher board independence are more attractive to outside investors, thereby expanding the company's shareholders and reducing the company's capital cost. At the same time, external investors (especially foreign institutional investors) will be more active in monitoring the companies they invest in, further promoting greater shareholder wealth. The introduction of independent directors in overseas contexts can improve corporate governance and improve company performance [8].

\section{A Literature Review on Directors' Supervision of Managers: From the Perspective of Equity Incentives}

Foreign research on equity incentives includes stock option pricing and accounting treatment; awarded to outstanding employees is also a senior manager and so on [9] [10] [11] [12] [13]. Combined with the research content of this paper, this paper mainly reviews the relevant documents that the grantees are senior managers and the exercise conditions include performance requirements. Kuang \& Qin used the UK's performance option data study from 1999 to 2004 to find that the use of performance options can lead to closer contact between management and shareholders [14]. Henry et al. found that when the optimal contract theory and risk sharing hypothesis were given to the executives with moderate over-remuneration and equity incentives, it would help to improve the effectiveness of internal control [15]. Jayaraman \& Milbourn found that using the auditor industry's professional competence as a monitoring and inspection mechanism, found that equity incentives increase executives' manipulation of the company's financial statements only in the auditor's professional competence, and in the auditor this phenomenon did not occur in a professionally competent environment [16]. Liu \& Liu found that an effective board of direc- 
tors can mitigate the negative negative impact of $\mathrm{CEO}$ volatility on major defect repairs in internal controls [17].

At present, Chinese scholars are very rich in the research on executives' equity incentives. It also explains the importance of research on the issues related to executives' equity incentives. For the listed companies, why do they choose equity incentives? Lv Changjiang et al. found that similar to foreign countries, the demand for human capital is the motivation for listed companies to choose equity incentives; imperfect governance structure and serious agency problems will also make the company have incentives to choose equity incentives [18]. Regarding the effectiveness of the performance-based equity incentives studied in this paper, Xie Deren and Chen Yunsen found that such equity incentive plans can increase wealth of shareholders, and the higher the performance requirements, the more contributing to the growth of shareholder wealth [19]. Xu Yu et al. found that equity incentives can reduce short-sighted behavior of executives, increase the effectiveness of internal controls, and reduce audit fees [20].

\section{Literature Summary and Comparative Criticism}

Through the above analysis of domestic and foreign literatures, it can be seen that most of the relevant literature on the supervision is carried out from the perspective of monetary compensation of directors and managers, and a considerable part is Research from the perspective of independent directors is followed by research on various aspects of the relationship between managers and board members, as well as external supervisory influence on managers or directors. But at the same time, there are relatively few studies on directors and managers. From the current research, it is mainly studied from the perspective of manager compensation or director compensation, including the shareholding ratio, individual characteristics and concurrent status of managers or directors. From the current research on the equity incentives of board members or senior executives, the research direction is basically based on the perspective of incentive effectiveness. It is mainly to study the influence of manager's equity incentives on corporate governance, because managers directly affect the company's information output quality. An option for directors as incentives is also a direction of research, although it only affects the company by affecting the quality of the information produced by managers. The same problem is that there is relatively little literature on the simultaneous research of directors and managers, especially in the context of equity incentives.

According to the tournament theory, monetary compensation incentives may be affected by various factors, such as industry pay, macroeconomics, etc. Directors and managers will use these external factors to defend their efforts and reduce their sensitivity to pay performance, thus obtaining more compensation. Directors also received more unsupervised compensation. These factors will result in lower compensation performance of directors and managers, which will reduce the proportion of directors' supervision and compensation to managers, 
thus weakening their supervision of managers. Then there will be an agency problem between directors and shareholders that Tilore believes [21]. Equity incentives will not have these shortcomings. This paper believes that the possibility of being affected by the above factors is very low when formulating the equity incentive plan. The equity incentive plan is mainly affected by the actual operation of the company, and will be strongly concerned by investors. Because whenever a company publishes a draft equity incentive plan, in the trading market, investors will vote with their feet to conduct strong supervision. Such supervision will enable listed companies to modify the relevant provisions of their equity incentive plans, so that directors fully consider the opinions of investors when formulating the equity incentive plan. This process is the process of director supervision. It is not easy to reduce the exercise requirements of the equity incentive plan because of the various rhetoric of the manager. At the same time, it will not increase the incentive intensity of the manager because of the various excuses of the manager. It can be seen that the director plays a key role in this process. According to the most paid contract theory, shareholders should consider this role of directors and give appropriate equity incentives.

\section{Conclusions and Suggestions}

The board of directors is an important mechanism for solving agency problems [22]. The board of directors can supervise important decisions of the company and determine the salary of managers. When the board of directors decides the manager's salary arrangement, it considers that it is necessary to increase the manager's business decision under the principle of maximizing the interests of shareholders through incentives, and equity incentive is a better choice, according to the optimal compensation contract theory. The main role is to reduce agency costs [23]. It can fully bind the interests of managers and the interests of shareholders to achieve the above incentive goals. In terms of the setting of the exercise conditions of the equity incentive plan, according to the theory of the optimal compensation contract, the incentive salary of the motivated person should be fully linked with the performance. Therefore, the requirements of the equity incentive law in China must have the performance conditions. Due to the generally low setting of the exercise performance conditions of China's equity incentive plan, the board of directors should consider increasing the exercise performance conditions as much as possible under the established incentive cost when formulating the equity incentive plan [24]. According to China's "Administrative Measures for Equity Incentives of Listed Companies", directors can also be the object of granting equity incentive plans. When directors are also granted equity incentives, according to Tilore's three-tier agency theory, the board is more active to the manager. People supervise, because directors can only influence the quality of information produced by supervision, and thus the incentive effect of CEOs is improved indirectly affecting company performance. Moreover, Cornelli et al. found that the board of directors can better understand the 
CEO's ability by collecting soft information [6]. Therefore, the board of directors will fully consider the CEO's ability when making performance conditions, and strive to make the performance conditions close to the CEO's maximum ability. The chairman and CEO respectively act as the top leaders in the board of directors and managers. When they jointly give equity incentives to them, the chairman will have more understanding and supervision of the CEO than other managers.

When the board of directors is responsible for supervising managers, the goal of the board should be to maximize shareholder value, especially in the context of equity incentives. At this time, the chairman and CEO are the community of interests, and under the active supervision of the chairman, they will work hard to achieve the maximum benefit, in order to achieve the performance requirements of the exercise requirements. At the same time, the manager will not achieve the exercise. The so-called performance manipulation is required or the use of power in the hands of the performance of the performance of the conditions to the downward or more easily reach the intervention [25] [26] [27] [28]. Because the optimal compensation contract theory and risk sharing hypothesis, while granting the chairman and $\mathrm{CEO}$ equity incentives, will increase the effectiveness of the company's internal control, which will make the chairman and CEO more willing to take risks. In the end, the manager and the board of directors make the company's performance meet the requirements of the performance of the performance, thereby maximizing the value of the company and maximizing shareholder value.

Finally, based on the research conclusions of this paper, the policy suggestions of this paper are proposed. First of all, for enterprises, when companies consider implementing equity incentives, they should strictly analyze the ability of the grantee and select the appropriate grantee. At the same time, after analyzing the strength of internal and external supervision, if internal and external supervision is strong, then enterprises should consider jointly granting equity incentives to directors and managers. If internal and external supervision is weak, then the equity incentive plan should be implemented cautiously. Then, for all shareholders and relevant government departments, companies that are only motivated by directors or CEOs should be strictly supervised because they have a strong self-interest and may take some self-interest to harm corporate value.

\section{Conflicts of Interest}

The author declares no conflicts of interest regarding the publication of this paper.

\section{References}

[1] Brick, I., Palmon, O. and Wald, K. (2006) CEO Compensation, Director Compensation, and Firm Performance: Evidence of Cronyism? Journal of Corporate Finance, 12, 403-423. https://doi.org/10.1016/j.jcorpfin.2005.08.005

[2] Linck, J.S., Netter, J.M. and Yang, T. (2008) The Determinants of Board Structure. Journal of Financial Economics, 87, 308-328. 
https://doi.org/10.1016/j.jfineco.2007.03.004

[3] Vafeas, N. (1999) Board Meeting Frequency and Firm Performance. Journal of Financial Economics, 53, 113-142. https://doi.org/10.1016/S0304-405X(99)00018-5

[4] Faleye, O., Hoitash, R. and Hoitash, U. (2011) The Costs of Intense Board Monitoring. Journal of Financial Economics, 101, 160-181. https://doi.org/10.1016/j.jfineco.2011.02.010

[5] Ivan, E. and Brick, N.K. (2010) Chidambaran. Board Meetings, Committee Structure, and Firm Value. Journal of Corporate Finance, 9, 533-553.

[6] Cornelli, F., Kominek, Z. and Ljungqvist, A. (2013) Monitoring Managers: Does It Matters? Journal of Finance, 68, 431-481. https://doi.org/10.1111/jofi.12004

[7] Miletkov, M.K., Poulsen, A.B. and Wintoki, M.B. (2014) The Role of Corporate Board Structure in Attracting Foreign Investors. Journal of Corporate Finance, 29, 143-157. https://doi.org/10.1016/j.jcorpfin.2014.06.005

[8] Oxelheim, L. and Randøy, T. (2003) The Impact of Foreign Board Membership on Firm Value. Journal of Banking \& Finance, 27, 2369-2392. https://doi.org/10.1016/S0378-4266(02)00395-3

[9] Aboody, D. (2006) Discussion of "Which Approach to Accounting Foremployee Stock Options Best Reflects Market Pricing? Review of Accounting Studies, 11, 247-251. https://doi.org/10.1007/s11142-006-9001-4

[10] Landsman, W.R., Peasnell, K.V., Pope, P.F. and Shu, Y. (2006) Which Approach to Accounting for Employee Stock Options Best Reflects Market Pricing? Review of Accounting Studies, 11, 203-245. https://doi.org/10.1007/s11142-006-9008-X

[11] Barth, M.E., Hodder, L.D. and Stubben, S.R. (2013) Financial Reporting for Employee Stock Options: Liabilities or Equity? Review of Accounting Studies, 18, 642-682. https://doi.org/10.1007/s11142-013-9230-2

[12] Core, J.E. and Guay, W.R. (2001) Stock Option Plans for Non-Executive Employees. Journal of Financial Economics, 61, 253-287. https://doi.org/10.1016/S0304-405X(01)00062-9

[13] Guay, W., Kothari, S.P. and Sloan, R. (2003) Accounting for Employee Stock Options. The American Economic Review, 93, 405-409. https://doi.org/10.1257/000282803321947425

[14] Kuang, Y.F. and Qin, B. (2009) Performance-Vested Stock Options and Interest Alignment. The British Accounting Review, 41, 46-61. https://doi.org/10.1016/j.bar.2008.10.001

[15] Henry, T.F., Shon, J.J. and Weiss, R.E. (2011) Does Executive Compensation Incentivize Managers to Create Effective Internal Control Systems? Research in Accounting Regulation, 23, 46-59. https://doi.org/10.1016/j.racreg.2011.03.007

[16] Jayaraman, S. and Milbourn, T. (2015) CEO Equity Incentives and Financial Misreporting: The Role of Auditor Expertise. The Accounting Review, 90, 321-350. https://doi.org/10.2308/accr-50854

[17] Liu, X.J. and Liu, X.H. (2017) CEO Equity Incentives and the Remediation of Material Weaknesses in Internal Control. Journal of Business Finance \& Accounting, 44, 1338-1369. https://doi.org/10.1111/jbfa.12265

[18] Lv, C.J., Zheng, H.L., Yan, M.Z. and Xu, J. (2011) Why Do Listed Companies Choose Equity Incentive Plans? Accounting Research, No. 1, 68-75.

[19] Xie, D. and Chen, Y.S. (2010) Performance-Based Equity Incentives, Exercise Performance Conditions and Shareholder Wealth Growth. Financial Research, No. 12, 99-114. 
[20] Xu, Y., Feng, J.K. and Li, R.J. (2017) Research on the Relationship between CEO Motivation, Media Concern and Internal Control Effectiveness. Audit and Economic Research, No. 2, 35-45.

[21] Tirole, J. (1986) Hierarchies and Bureaucracies: On the Role of Collusion in Organizations. Journal of Law, Economics \& Organization, 2, 181-214.

[22] Fama, E.F. and Jensen, M.C. (1983) Separation of Ownership and Control. The Journal of Law and Economics, 26, 301-325. https://doi.org/10.1086/467037

[23] Wan, H.L. (2018) A Review of Equity Incentives and Corporate Finance Research. Accounting Research, No. 5, 52-58.

[24] Xiao, S.f., Liu, Y. and Liu, Y. (2013) Research on Managers' Earnings Management Behavior in Stock Option Implementation: Setting Angle of Performance Evaluation Indicators. Accounting Research, No. 12, 113-119.

[25] Bebchuk, L.A. and Fried, J.M. (2003) Executive Compensation as an Agency Problem. Journal of Economic Perspectives, 17, 71-92. https://doi.org/10.1257/089533003769204362

[26] Morse, A., Nanda, V. and Seru, A. (2011) Are Incentive Contracts Rigged by Powerful CEOs? The Journal of Finance, 66, 1779-1821. https://doi.org/10.1111/j.1540-6261.2011.01687.x

[27] Xie, D., Cui, Y. and Tang, X. (2018) Performance-Based Motives and Real Earnings Management under Performance-Based Equity Incentives. Nankai Management Review, 21, 159-171.

[28] Yermack, D. (1997) Good Timing: CEO Stock Option Awards and Company News Announcements. The Journal of Finance, 52, 449-476.

https://doi.org/10.1111/j.1540-6261.1997.tb04809.x 